\author{
Geology and geophysics
}

http://www.journalesgia.com

\title{
ASSESSMENT OF GEODYNAMIC RISK OF MINGACHEVIR WATER RESERVOIR
}

\author{
Islamova Sh.K., Kazimova S.E., Ismailova S.S. \\ Republican Seismic Survey Center, Azerbaijan National Academy of Sciences \\ 9, N.Rafibeily str., Baku, AZ1001, Azerbaijan: shirin.i@inbox.ru, sabina.k@mail.ru
}

Keywords: Mingachevir reservoir, seismic activity, earthquake, landslides
Summary. The paper presents the results of the analysis of seismicity, tectonics and the manifestations of induced seismicity in the area of the Mingachevir reservoir for the period 2008-2017. Local earthquakes that occur when the Mingachevir reservoir is filled have insignificant magnitudes - less than 2-2.5, tremors with a magnitude of 3.5 are less common. Epicenters are located mainly at a distance of no more than 5-10 km. Data analysis showed that seismic activity increases when the pressure reaches $78 \mathrm{~m}$ or more. Based on the mechanisms of the earthquake source, maps of the distribution of compressive and extension stresses in the horizontal plane and in depth were constructed. It was found that the northwestern part of the study area is characterized by extension and compression in the south and southeast. Analysis of seismic activity observation data showed the dependence of the rate of change of the water level in the reservoir with the seismic activity of weak earthquakes, which is non-linear. The rise in water level lasts 5 months, from March to June. In August the water level at the beginning drops gradually and then sharply (from 80-78 $\mathrm{m}$ to 74 $73 \mathrm{~m}$ ). As a result of the drop in water level in this area the induced seismicity increased. In 2010 the water level in the Mingachevir reservoir increased from 78-79 meters in March to 82-83 meters in May, caused an increase in the water level in the Kura River and attracted flooding. An analysis of seismicity for this period showed that in February, March, April, July and August 21 earthquakes with magnitudes of 1.2-3.0 occurred in this region

(C) 2019 Earth Science Division, Azerbaijan National Academy of Sciences. All rights reserved.

\section{Introduction}

As it is known the territory of Azerbaijan is under influence of natural disasters which occur occasionally, they are: landslides, earthquakes, mudflows, floods, etc., the most dangerous and unpredictable among them are earthquakes.

Water is an efficient instrument in man's impact on seismicity and seismic conditions in seismic active regions. The construction of large reservoirs and other hydraulic structures causes an increase of seismic activity.

Filling large dams could change the stress state of active seismic regions, causing the occurrence of earthquakes. This problem is urgent for our republic as the country is one of the active seismic regions in the Caucasus.

Several water reservoirs are functioning in the Azerbaijan territory including Mingachevir water reservoir and they are able to change seismic conditions of region.

Study of earthquake prone factors of Mingachevir water reservoir is of practical and theoretic importance, it allows studying both tectonic struc- ture and seismicity of region in details. Moreover research of these factors permits to withstand undesirable consequences during natural disasters and optimally exploit hydrotechnical constructions.

This article mainly focuses on studying earthquake-prone factors in the territory of Mingachevir water reservoir, definition of connection between seismicity and water conditions in reservoir and determination of hydrostatic impact nature on landslide activization within studied region.

\section{General description of Mingachevir water reservoir}

Mingachevir water reservoir is located in natural tectonic mouldlike depression of Kura valley passing into thick anticlinal uplifts framing Bozdag ridges in the south and Kojashen in the north (Fig. 1).

Water reservoir extends from NW to SE along Kura r. valley approximately $75 \mathrm{~km}$ including partially Alazani r. valley. The area of water reservoir aquatorium is about $625 \mathrm{~km}^{2}$, and average width is 6-8 $\mathrm{km}$. Length of coastline is $215 \mathrm{~km}$. Volume of water reservoir is $16 \mathrm{~km}^{3}$. Mingachevir water reser- 
voir surrounded by high ridges is located in favorable conditions and represents natural tectonic bowl having the same morphological surface. Khanabad valley is the only low area where saddle connects Bozdag and Kojashen ridges with the higher mark (Islamov, 1963).

Mingachevir water reservoir was filled in 1953 when Mingachevir hydraulic complex appeared covering Kura r. in area of Mingachevir throat.

Relief of Mingachevir water reservoir area can be characterized by complexity and diversity. The main geomorphological structure of studied region is Bozdag ridge represented by anticlinal fold of flattopper type. Bozdag consists chiefly of Absheron sandy-clayey rocks and only in the crystalline part akchagyl dark-grey, almostly black clays can be found as sports (Suleimanov, 1961).

This main geomorphological structure is added by inclined piedmont foreslopes overlapping two large erosion steps.

North-eastern slope of Bozdag ridge is of typical landslide structure.
North-eastern slope of Bozdag coinciding with arc part of anticline gradually passes into the area of hilly relief development on flattened Bozdag top. South-western slope of Bozdag ridge is represented by bush relief area.

Relief is formed in relatively dry climate. Sea transgressions from south-east abraded south slopes of Bozdag and eliminated southern slope of the main fold.

\section{Mingachervir water reservoir silting}

Building of Mingachevir dam and construction of large water reservoir provided the change of Kura r. rate regime. This disturbed recorded regime of sediments movement and created conditions for their bedding in water reservoir. In practice of hydraulic structures there were situations when newly built water reservoirs became silty fast. So, study of conditions of sediments accumulation and definition of silting duration of Mingachevir water reservoir is of great importance.

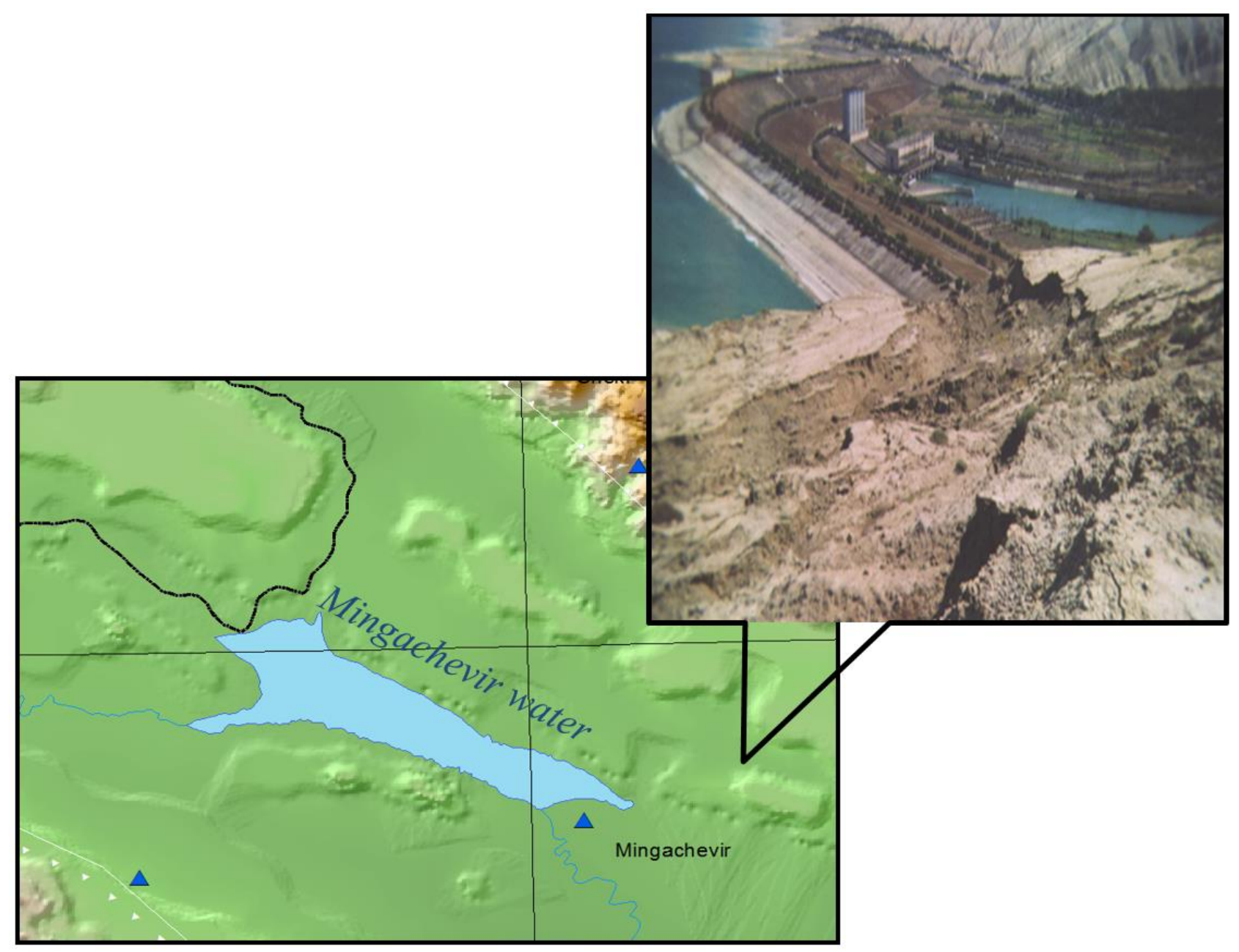

Fig 1. Schematic map of Mingachevir water reservoir region 
Within water reservoir one can determine morphologically the area of piedmonts and mountains of surrounded ridges, average height of which is 200$250 \mathrm{~m}$. The higher water levels in water reservoir can be found in summer months and this is connected with hydrometeorological phenomena in area of water reservoir. Increase of water level in water reservoir continues usually 5 months - from March till July and maximum intensity is in May-June. In August fall of water occurs; at the beginning - slowly and then - rapidly. In January-March level fluctuations are insignificant. Spring and summer increase of water level is caused both by water coming from Kura, Iori and Alazan rivers and by sediments in water reservoir. Reduction of water level in water reservoir during autumn-winter period is caused on the one hand - by drought type of supply, and on the other hand - by regime of water reservoir work on energetic schedule.

Spring overflow in Mingachevir water reservoir is the consequence of two factors relationship melting of snow gathered in mountains and spring sediments. Gradual coming of spring water starts in March. Average duration of overflow is from 2.5 till 3 months. Start and finish terms of overflow on three rivers coincide. Moreover, artificial distribution of water irrigation influences greatly on flow regime. Correspondingly expenditure of suspended sediments depends on change of water expenditure.

Ground waters of Absheron and Akchagyl deposits are confined to root sandstones but as a result of strong and deep erosion of ridges components they are heavily drained and aquifers of Absheron more drained.

\section{Seismicity of studied region}

At present RCSS of ANAS includes 35 seismotelemetric stations, seven of which are located in the territory of Middle Kura depression.
Owing to improvement of monitoring system now it is possible to register earthquakes with $\mathrm{ml}>0.1$ without interruption. According to map of earthquakes epicenters for three periods 427-1953, 1954-2017 and 2003-2017 yrs. the Mingachevir focal area can be defined as zone with 6-7 M (Fig. 2, 3) (Report on the work of the experimental batch processing, 1981-2007).

These periods were chosen because the exploitation of the reservoir was started in 1954, and it was interesting to see how the seismic situation in this region changed. The period from 2003 to 2017 was shown in order to understand whether the impact of new open digital stations in Azerbaijan affected the number of recorded earthquakes in the Mingachevir reservoir area. An increase in the network of digital stations made it possible to record weaker seismic events. But despite this, it can be concluded that seismic activity in this region has increased compared to the period when the reservoir was not built, i.e. induced seismicity appeared.

On the basis of the macroseismic and instrumental data analysis collected in the Azerbaijan territory for the period of the last 400 years, it has been determined that the strong and weak earthquakes foci in Azerbaijan are mainly situated within the crust and correspond to $10-30 \mathrm{~km}$ depths. Thereby relatively small amount of these events is connected with deep depths (Fig. 4) (Geology of Azerbaijan, 1951).

On the basis of the macroseismic and instrumental data analysis it was determined that both strong and weak earthquakes occurred in Mingachevir water reservoir. But small earthquakes happen most often. In spite of this there is a necessity for seismicity monitoring in this territory because these small earthquakes eventually form small fractures in Mingachevir water reservoir. This can not only cause strong earthquakes but also lead to environmental hazards of Mingachevir water reservoir (Javakhishvili, 2002).

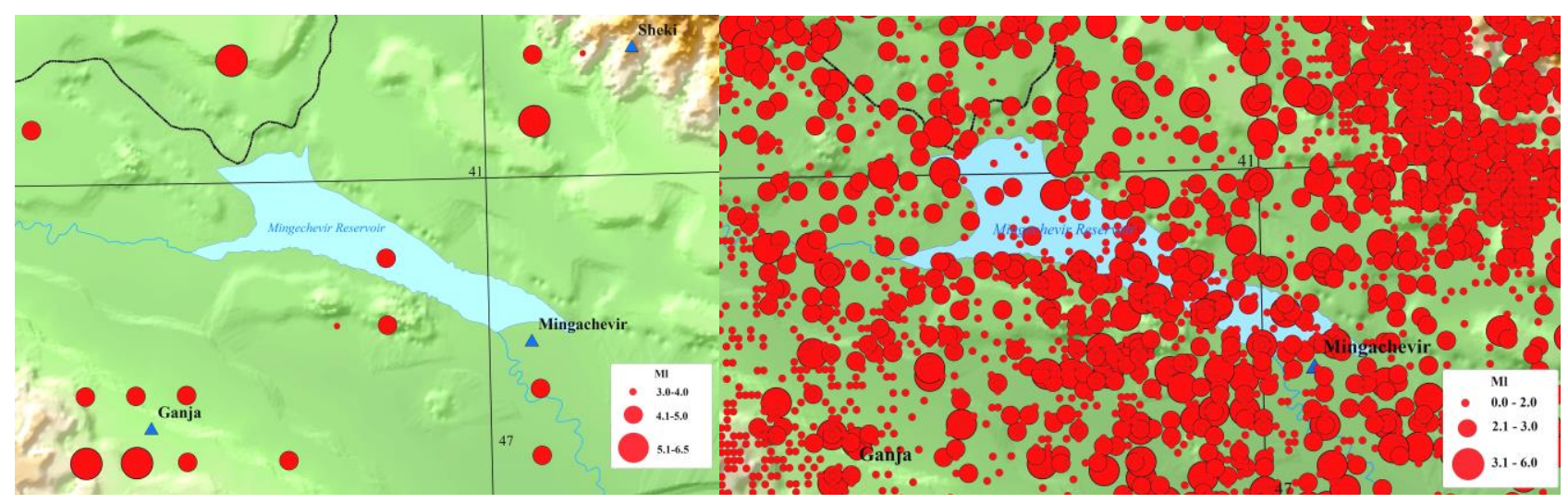

Fig. 2. Map of Mingachevir region epicenters and adjacent areas for the period 427-1953 and 1954-2017 yrs. 


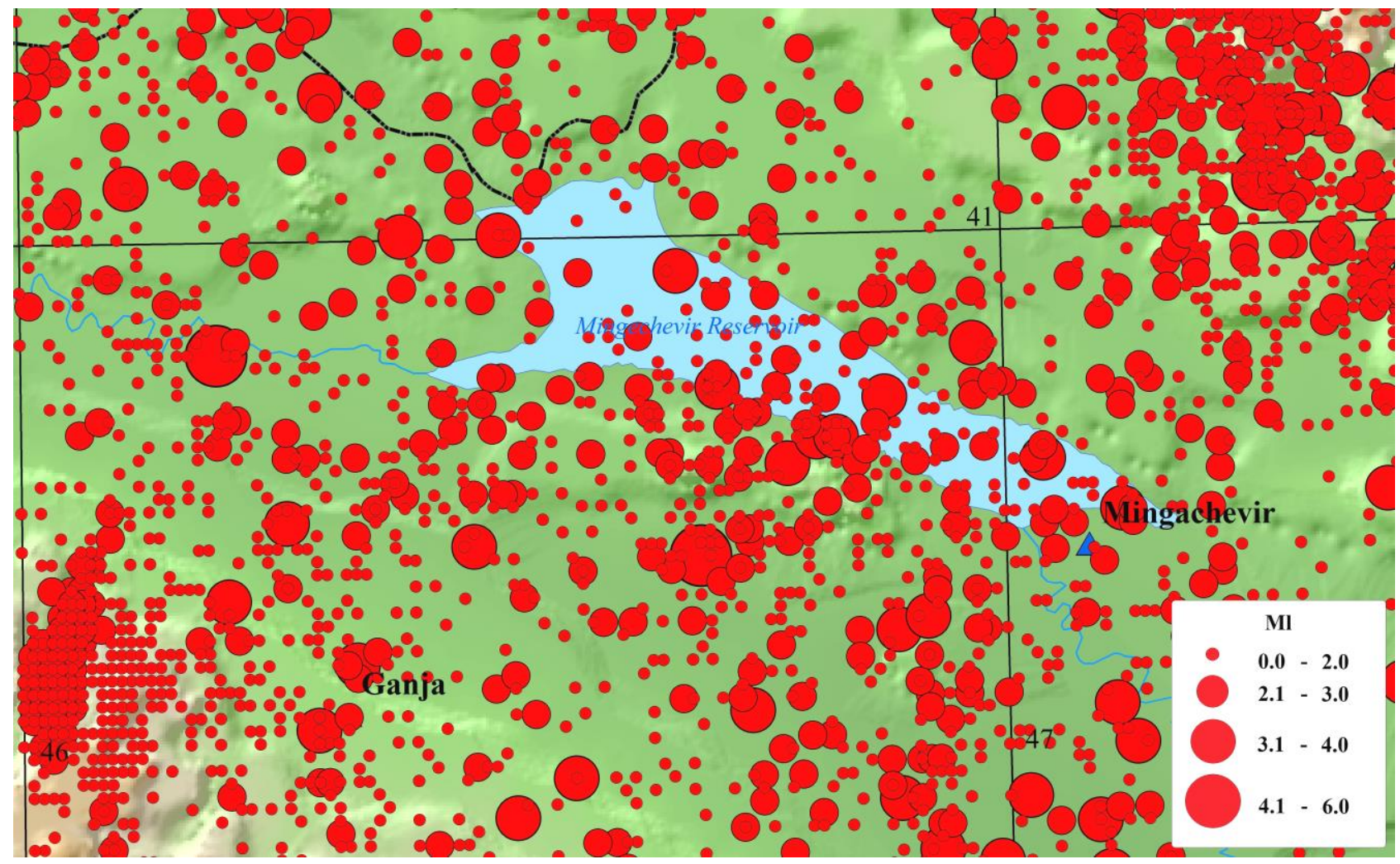

Fig. 3. Map of Mingachevir region epicenters and adjacent areas for the period 2003-2017 yrs

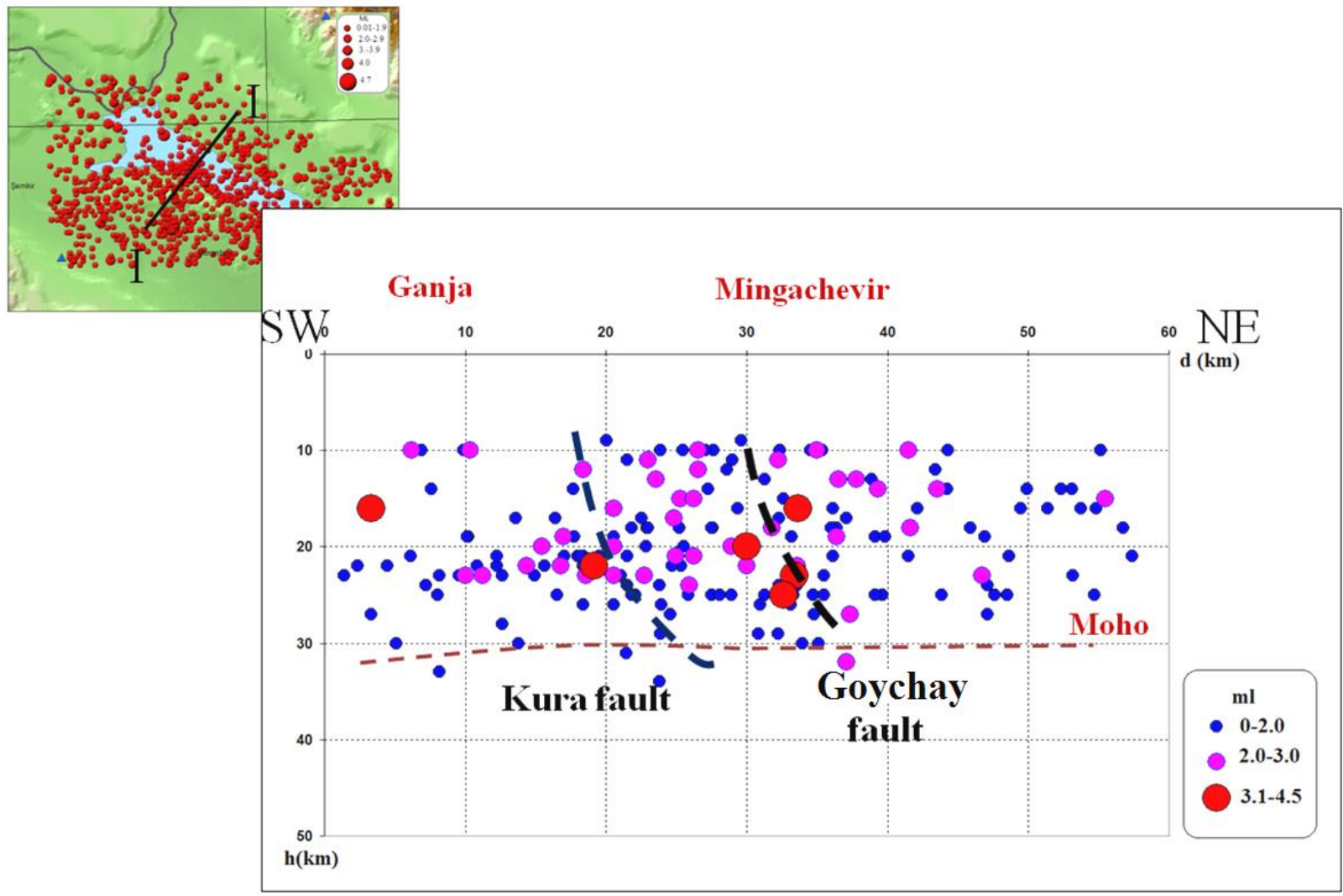

Fig. 4. Depth section of earthquakes hypocenters in Mingachevir water reservoir zone 
Based on these data it can be concluded either about supposed fault or about existence of medium inhomogeneity of stress fields at this depth and that earthquakes of this focal area can be coincided with them.

Scientists investigating the seismicity of this focal zone made a conclusion that both shallow earthquakes connected with the sedimentary cover and enough deep ones related to the "basaltic" layer and even to the transient formations from crust to mantle are characteristic of Mingachevir focal area.

The hypocentres distribution within investigated area for the period of 1980-2010 indicates an increase of seismic activity in 1980-1986, 1999-2004.

The studies show that the seismic activity has associated with the water reservoir level change. Maximum seismic activity and a large number of shocks occurred in 1982. The earthquake with $M=6$ magnitude happened on 3 May of the same year. Time shift between the water level peaks and seismic activity was several months.

The great repetition frequency of local earthquakes in Mingachevir region and its geological conditions taking into account modern tectonic movements create a real threat for construction sites.

A comparative analysis of reservoir water level changes against the energy released during earthquakes has been conducted by us for background seismicity research and seismic hazard determination.

The graphics for the period of 2008-2017 are presented as an example (Fig. 5).

Observational data analysis for seismic activity showed in the water reservoir existence of water level dependence on the seismic activity of small earthquakes which is non-linear. Seismic energy increase is observed in the interval of 1-3 months after reaching of maximum water level.

The seismic activity increase can also be connected with other influencing factors: additional load, tectonic faults existence, flooding, pore pressure change and etc. (Veliyev, 2001).

Earthquakes area influence on Mingachevir water reservoir zone was estimated according to the happened earthquakes magnitude within investigated region.

\section{Stress orientation distribution by Lode-Nadai method}

Methods of analysis of seismological data about earthquake source mechanisms and geological information of orientation of slip fault sets are wellknown in inverse problem of tectonophysics. These methods of stress inverse problem make it possible to calculate four out six components of tectonic stress tensor based on data on discontinuous dislocation: orientation of three principal stress axis $\left(\sigma_{\mathrm{k}}\right.$, $\mathrm{k}=1,2,3$ ), determined by three Euler's angles and
Lode-Nadai or ratio coefficient characterizing shape of stress tensor. A high value of the Lode-Nadai $\mu_{\sigma}$ coefficient indicates tension, a low value indicates compression. The Lode-Nadai $\mu_{\sigma}$ coefficient within the study area almost everywhere corresponds to a stress tensor of pure shearing (deviatoric stresses of maximum compression and tension have almost equal absolute values). In the transition zone from Kur basin toward NE zone of Greater Caucasus the stress tensor type corresponds to uniaxial compression (absolute value of deviatoric compression is two times larger than the other two principal stresses, which have almost the same value) (fig 6.).

\section{Physical and geological conditions on the Mingachevir reservoir banks}

Periodically horizons fluctuations of the Mingachevir reservoir while in service create the conditions for the change of existing physical-geological conditions of the water reservoir bowl slopes.

The wave-cut processes, storm flows having argillaceous karst on the slopes contribute to the slopes dissection intensification of the water reservoir basin bowl, which in its turn causes the landslides during periodic fluctuations of water line (Yetirmişli, 2006).

The numerous wave-cut notches of different sizes are formed under the waves slaps in the basis of coastal cliffs. These wave-cut notches in large quantities are observed above the dam on the south slope of the water reservoir. During high water level these positions are injected by water forming small inlets with vertical walls.

As a result of conducted surveys the following banks types are distinguished in the coastal zone of Mingachevir water reservoir: 1) accumulative areas; 2) abrasion bank: a) abrasion-collapse bank; b) abrasion-landslide bank, c) low level flood bank (Suleimanov, 1961).

Accumulative areas are essentially developed in the piedmont plain region, between ridge branches, downward to the water reservoir. In particular, they are occurred in the south-eastern and south-western areas.

Abrasion-collapse bank type is typical for the south-south-eastern bank of the water reservoir where the branch tips of the Bozdagh ridge, jutting out deeply into the sea, are exposed to the intense undercutting and caving.

Abrasion-landslide bank type is developed on the south bank of the water reservoir, directly at the HPS neck.

In the studied region the collapses play role of constant factor of the slopes formation. In addition, the ridges slopes, bordering the water reservoir, are covered by landslides. Landslides represented a complex phenomenon, conditioned by cohesion forces change. 
Geology and geophysics

2008 year

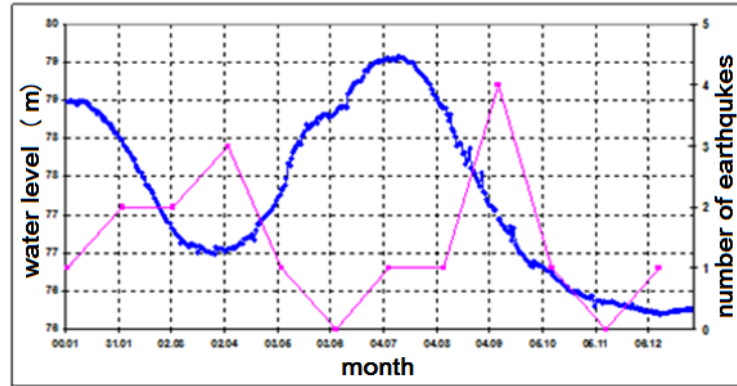

2010 year

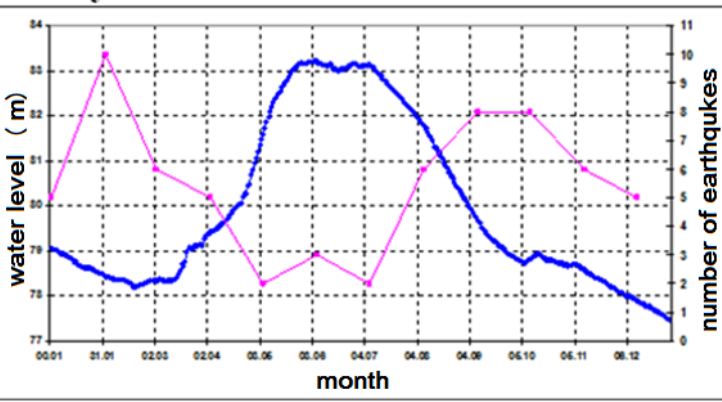

2012 year

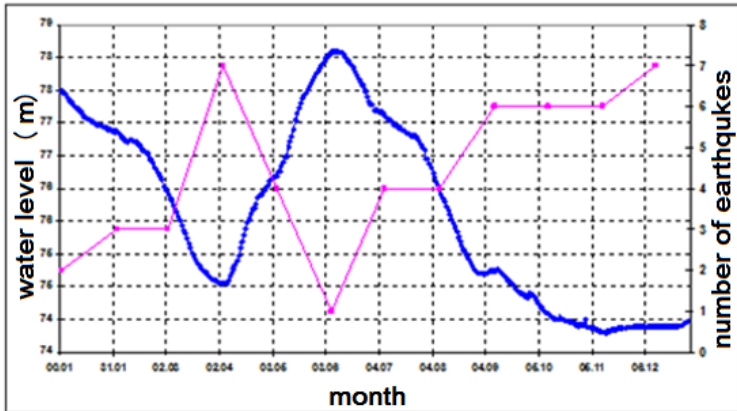

2014 year

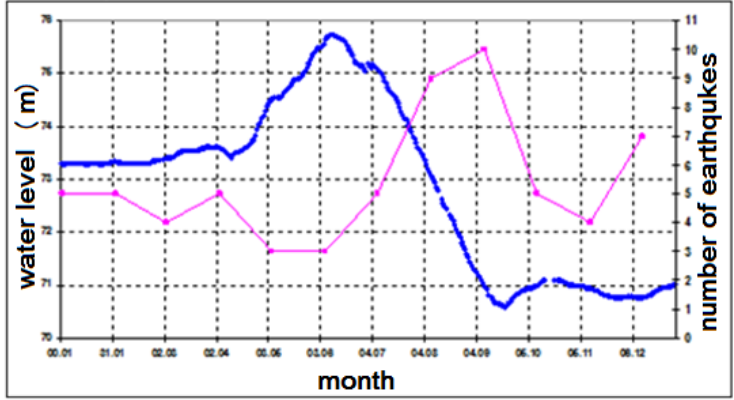

2016 year

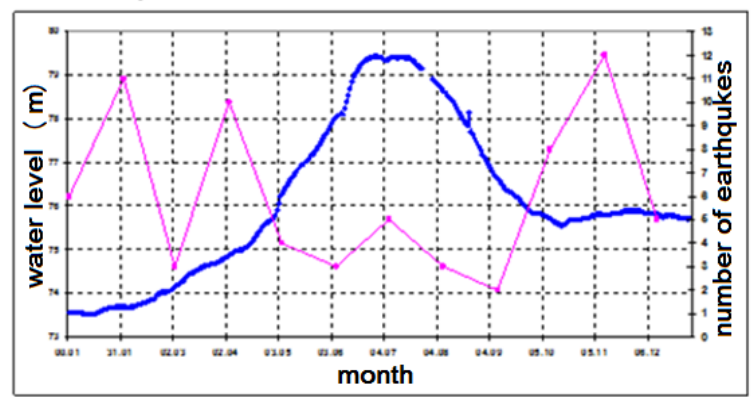

2009 year

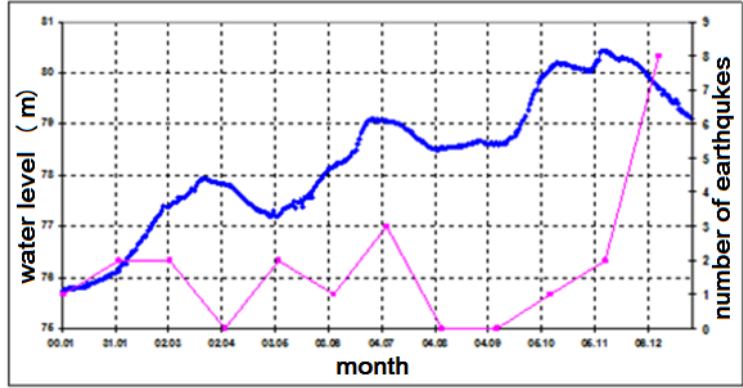

2011 year

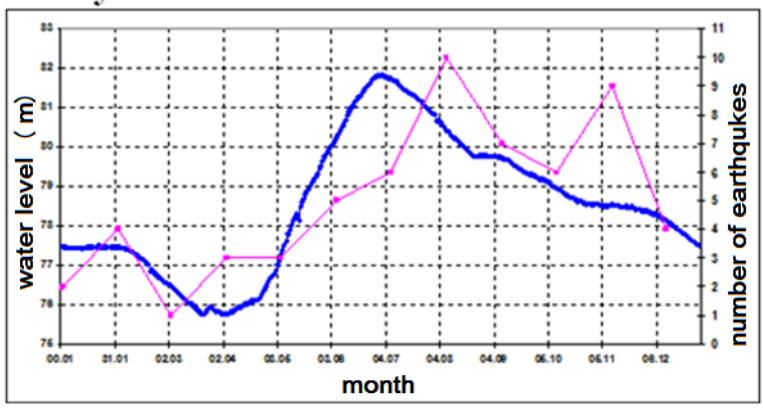

2013 year

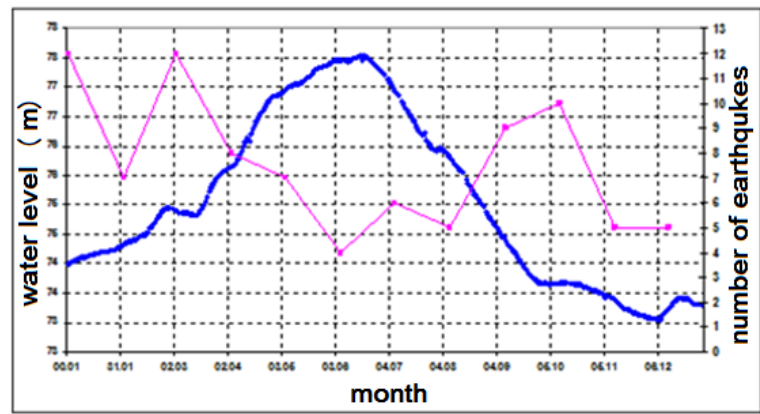

2015 year

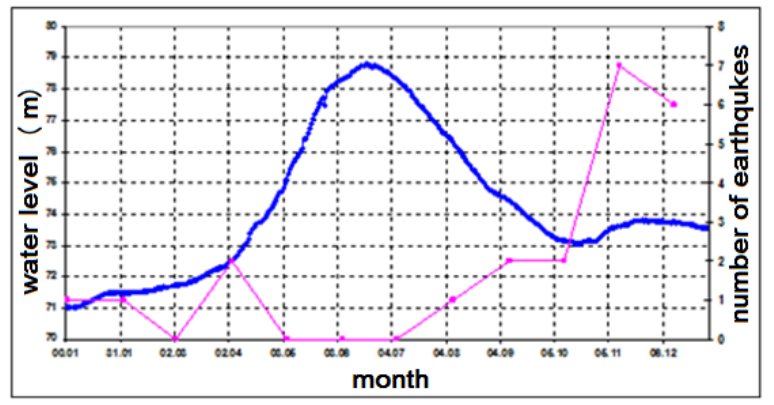

2017 year

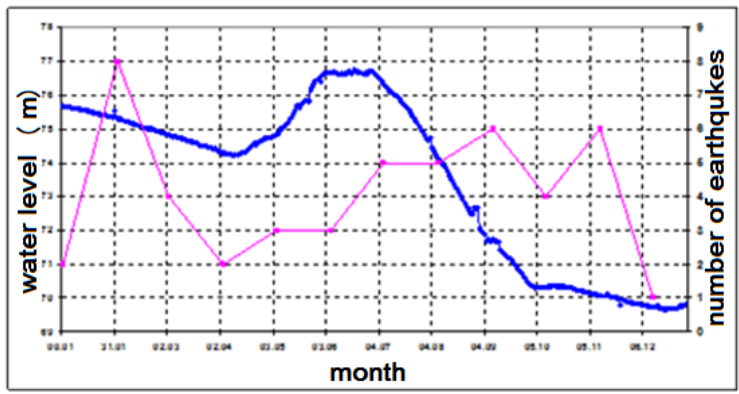

Fig. 5. Graphic of the reservoir water level change against energy released during earthquakes in 2008-2017 

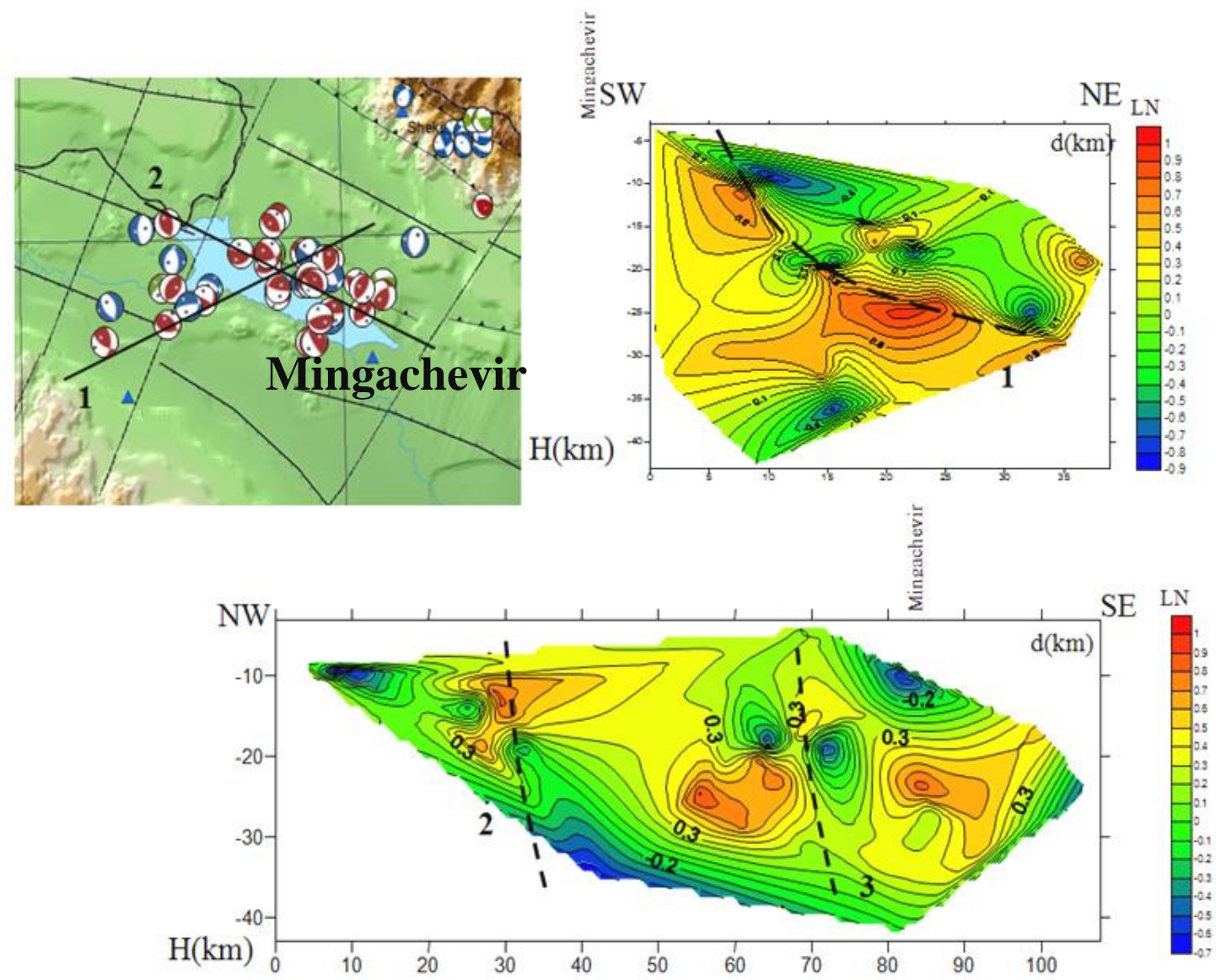

Fig. 6. Stress orientation by Lode-Nadai coefficient for the Mingachevir reservoir

It is known that the landslides occurred on the right bank of Mingachevir water reservoir, within Bozdag ridge in 1985, 1987, 1989, 1996, 2000, 2006 and 2012.

In order to study the hydrostatic impact effect on landslides activation within the studied region we have been conducted a comparative analysis of water level changes in water reservoir with the energy released during earthquakes and landslides processes in 1985, 1989, 1996, 2000 and 2006 (Fig. 7, 8).

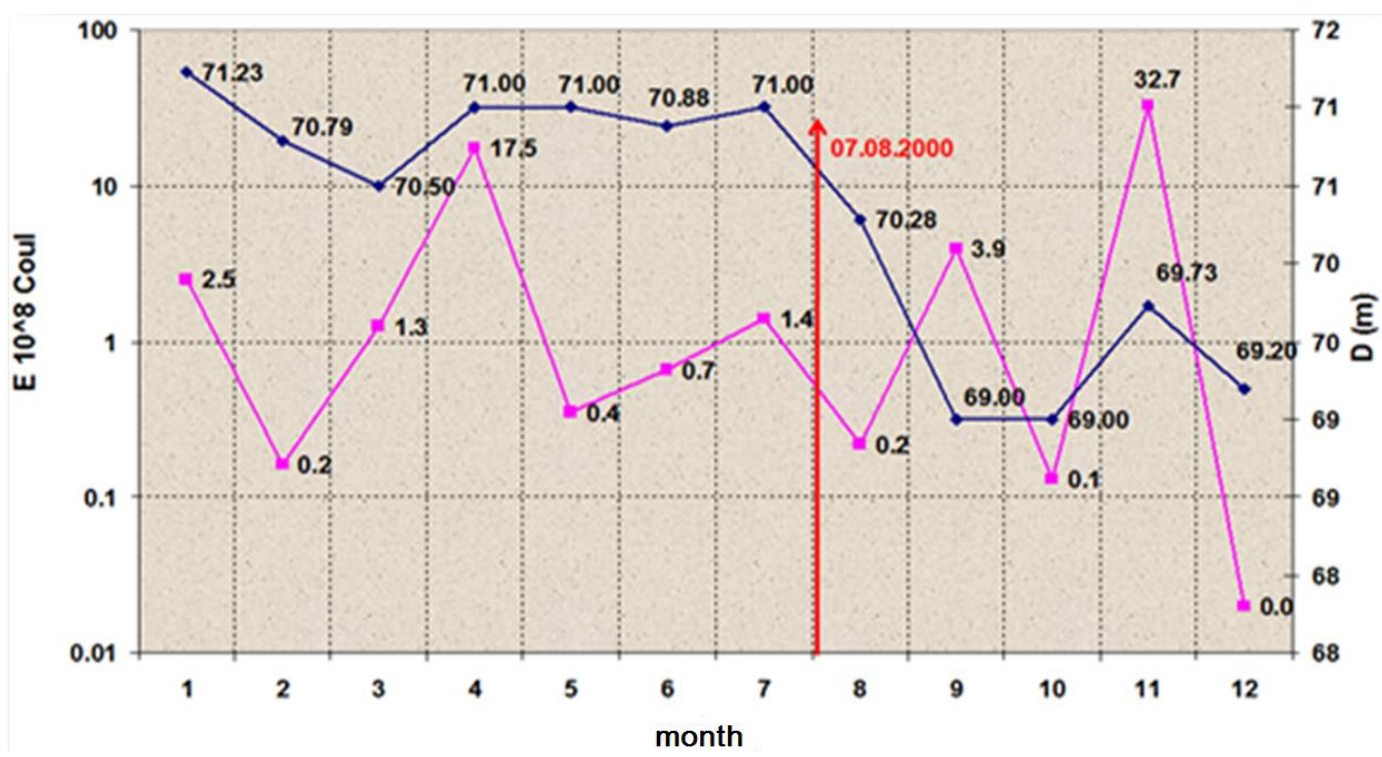

Fig. 7. Dependence diagram of the water level change of water reservoir with energy released during earthquakes by landslides activation for 2000 


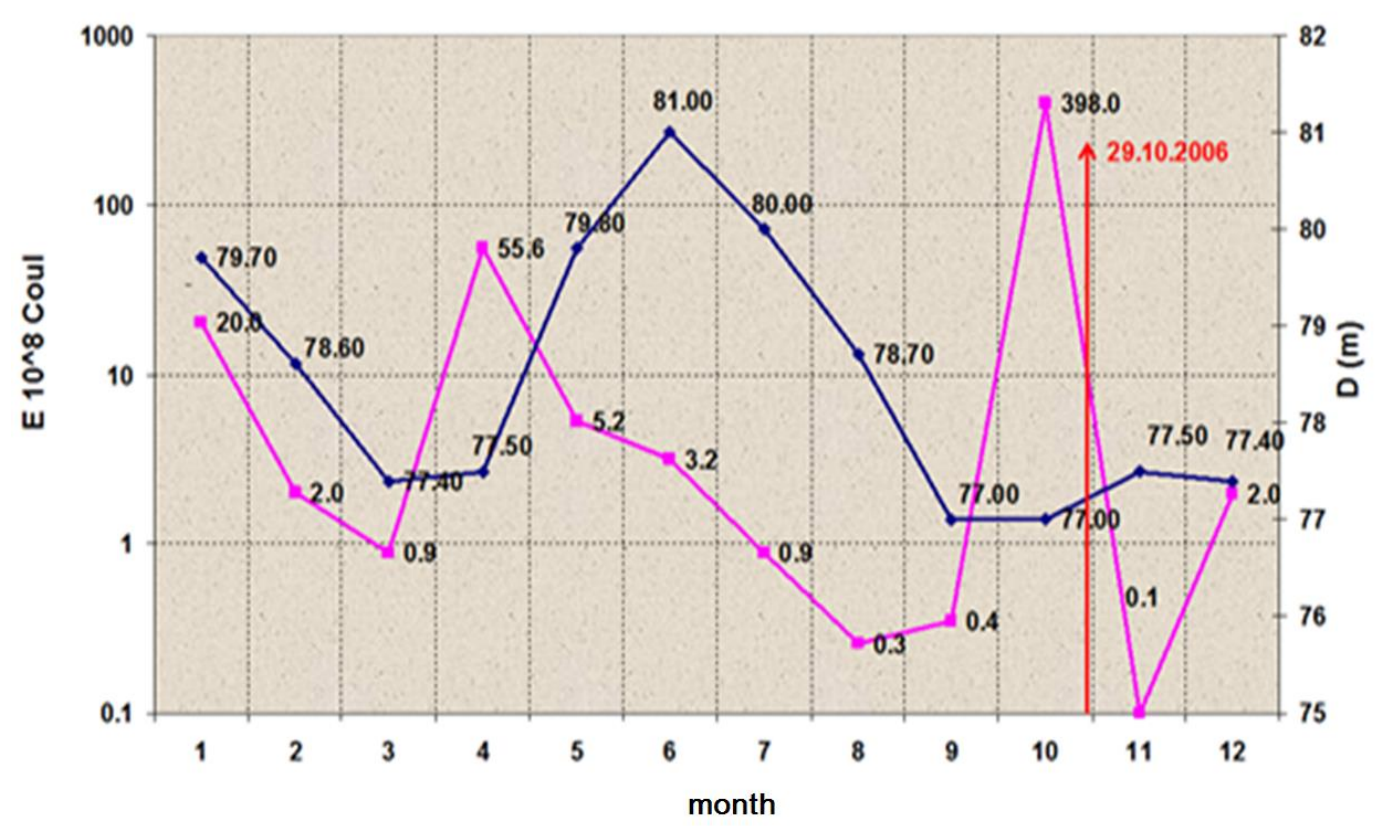

Fig. 8. Dependence diagram of the water level change of water reservoir with energy released during earthquakes by landslides activation for 2006

Seismic energy was calculated by the empirical method through the magnitude of earthquakes $(1,2)$ :

$$
\begin{aligned}
& \mathrm{K}=4.58+1.46 \mathrm{ml} \quad \mathrm{r}=0.8871, \mathrm{n}=1149 \\
& \mathrm{E}_{(\mathrm{enrg})}=10^{\mathrm{K}}
\end{aligned}
$$

The analysis showed that the landslides occurred mainly in summer-time during the fall in water level on 5-10 m, which is associated with the hydrostatic pressure decrease, change of argillaceous rocks plasticity, heavy rains and water seepage through water reservoir cracks.

\section{REFERENCES}

Geology of Azerbaijan. V. 1. AN Azerb. SSR, 1952, pp. 214359 (in Russian).

Islamov K.Sh. Instrumental studies of the MingechaurKirovabad zone (report for 1962-1963). The Fund of the Institute of Geology of the Academy of Sciences of Azerbaijan SSR, 1963, 152 p. (in Russian).

Javakhishvili Z.Sh. Seismic hazard and seismicity of the Inguri HES territory. İn: Geodynamic studies of large dams. Tbilisi, 2002, pp. 88-96 (in Russian).

Report on the work of the experimental batch processing and interpretation of seismological materials on the seismicity of Azerbaijan for 1980-2006. ANAS RSSC, Baku, 19812007, 118 p. (in Russian).

Suleimanov D.M. Issues of physical and geological phenomena on the banks of the Mingachaur reservoir. AS of Az.SSR Baku, 1961, 89 p. (in Russian).

Veliyev H.N. Methods for the discovery of oil and gas objects neglected by the effects of geodynamic-geotextonic tension

\section{Conclusion}

Reservoir filling influences the small earthquakes appearance directly in the Mingachevir water reservoir region and in the adjacent territories. During plain flooding the underground waters level rises in the soil foundation that induces the landslides formation. Moreover the right bank of water reservoir is the most probable place where one would expect the landslide phenomena. In addition, it should be noted that the high terraces in the cliffs areas and on the mountain slopes will collapse and adapt to the new conditions, which will cause the local origin drifts accumulation in the water reservoir.

\section{ЛИТЕРАТУРА}

Геология Азербайджана. Т. 1. Изд. АН Азерб. ССР, 1952, c. 214-359.

Джавахишвили 3.Ш. Сейсмическая опасность и сейсмичность территории Ингури ГЭС. Геодинамические исследования больших плотин, Тбилиси, 2002, с. 88-96.

Исламов К.Ш. Инструментальные исследования Мингечаур-Кировабадской зоны (отчет за 1962-1963 гг.). Фонды Института Геологии АН Азерб. ССР 1963, $152 \mathrm{c}$.

Отчет о работе опытно-методической партии обработки и интерпретации сейсмологических материалов по сейсмичности Азербайджана за 1980-2006 гг. РЦСС НАНА, Баку, 1981-2007, 118 с.

Сулейманов Д.М. Вопросы физико-геологических явлений на берегах Мингечаурского водохранилища. Изд.АН Аз.ССР. Баку, 1961, 89 с.

Vəliyev H. Neft yataqlarında geodinamik-geotektonik gərginliyin təsirindən nəzərdən yayınmiş neft-qazlı obyektlərin aş- 
on oil fields. Publishing of Azerbaijan National Encyclopedia. Baku, 2001, pp. 57-62 (in Azerbaijani).

Yetirmishli G.J. Methods of considering tension-deformation factors in seismic zoning of the territory of Azerbaijan. Elm. Baku, 2006, pp. 88-93 (in Azerbaijani). kar olunması metodikası. Azərbaycan milli ensiklopediyası nəşriyyatı. Bak1, 2001, c. 57-62.

Yetirmişli Q.C. Azərbaycan ərazisinin seysmik rayonlasdırılmasında gərginlik-deformasiya amillərinin nəzərə alınması metodikası. Elm. Bak1, 2006, cc. 88-93.

\title{
ОЦЕНКА ГЕОДИНАМИЧЕСКОГО РИСКА МИНГЯЧЕВИРСКОГО ВОДОХРАНИЛИЩА
}

Исламова Ш.К., Казымова С.Э., Исмаилова С.С.

Республиканский Центр Сейсмологической Службы НАН Азербайджана AZ1001, г. Баку, ул. Н. Рафибейли, 25: shirin.i@inbox.ru, sabina.k@mail.ru

Резюме. В работе приводятся результаты анализа сейсмичности, тектоники и проявления наведенной сейсмичности в районе Мингячевирского водохранилища за период 2008-2017 гг. Локальные землетрясения, возникающие при заполнении Мингячевирского водохранилища, имеют незначительные магнитуды - менее 2-2.5, реже проявляются толчки с магнитудой 3.5. Эпицентры располагаются в основном на расстоянии не более 5-10 км. Анализ данных показал, что сейсмическая активность возрастает при достижении напора 78 м и более.

На основании данных механизмов очагов землетрясений были построены карты распределения напряжений сжатия и растяжения в пространстве и по глубине. Было установлено, что северо-западная часть исследуемого района характеризуется растяжением и сжатием на юге и юго-востоке.

Анализ данных наблюдений за сейсмической активностью показал наличие зависимости скорости изменения уровня воды в водохранилище от сейсмической активности слабых землетрясений, которая имеет нелинейный характер. Повышение уровня воды длится 5 месяцев, начиная с марта по июнь. В августе месяце уровень воды сначала постепенно, а затем резко падает (с 80-78 м до 74-73 м). В результате падения уровня воды в этом районе увеличилась наведенная сейсмичность.

В 2010 году уровень воды в Мингячевирском водохранилище повысился с 78-79 метров в марте до 82-83 метров в мае, что вызвало повышение уровня воды в реке Куре и повлекло за собой наводнение. Анализ сейсмичности за этот период показал, что в феврале, марте, апреле, июле и августе месяцах в данном регионе произошло 21 землетрясение с магнитудой 1.2-3.0.

Ключевые слова: Мингячевирское водохранилище, сейсмическая активность, землетрясения, оползни

\section{MINGOÇEVIR SU HÖVZəSINIIN GEODINAMIK RISSKININ QIYMəTLəNDİRILMəSi}

\author{
İslamova Ş.K., Kazımova S.E., İsmayılova S.S. \\ AMEA nəzlində Respublika Seysmoloji Xidmət Morkəzi \\ AZ1001, Bakl, N.Rafibeyli, 25: shirin.i@inbox.ru, sabina.k@mail.ru
}

Xülasə. Məqalədə Mingəçevir su anbarı ərazisində 2008-2017-ci illər üçün meydana gələn seysmikliyin, tektonikanın təhlili və suni zəlzələlərin əmələ gəlməsi prosesi analiz olunur. Mingəçevir su anbarı doldurulduqda baş verən yerli zəlzələlərin maqnitudaları əsasən 2.0-2.5 aralıqda dəyişir, 3.5 bal gücündə zəlzələlərə isə daha az rast gəlinir. Episentrlər əsasən 5-10 km dərinliklərdə yerləşir. Məlumatların təhlili göstərdi ki, suyun səviyyəsi $78 \mathrm{~m}$ və ya daha çox olduqda seysmik aktivlik artır.

Zəlzələ ocaq mexanizmlərinin alınmış məlumatlar əsasında sıxılma və gərilmə zonalarının sxemi və dərinliyə görə kəsilişlər qurulmuşdur. Müəyyən olunub ki, tədqiq olunan ərazinin şimal-qərb hissəsi gərilmə ilə səciyələnir, orta hissələrində horizontal yerdəyişmə, cənub və cənub-şərq hissələrində isə sıxılma müşahidə olunur. Su anbarının doldurulması birbaşa Mingəçevir su anbarı rayonunda və bitişik ərazilərdə zəif zəlzələlərin meydana gəlməsinə təsir göstərir.

Su anbarında suyun səviyyəsinin qalxması adətən 5 ay - mart ayından iyul ayına qədər davam edir. Avqustda suyun səviyyəsinin düşməsi başlayır: əvvəlcə yavaş-yavaş, sonra isə daha sürətlə (80-78 m-dən 74-73m-ə qədər). Yanvar-mart aylarında suyun səviyyəsinin dalğalanması az miqdarda olur.

2010-cu ildə Mingəçevir su hövzəsində suyun səviyyəsi mart ayında 78-79 m-dən may ayında 82-83 m-ə qədər yüksəlmişdir ki, bu da Kür çayında suyun səviyyəsinin artmasına və daşqına səbəb olmuşdur. Həmin vaxt ərzində seysmikliyin analizi göstərdi ki, fevral, mart, aprel, iyul və avqust aylarında bu bölgədə 1.2-3.0 bal gücündə 21 zəlzələ baş vermişdi.

Açar sözlor: Mingaçevir su anbarl, seysmik aktivlik, zəlzəla, sürüşmə 